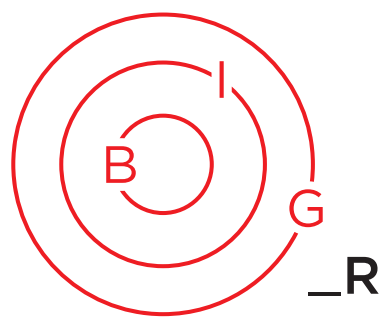

ARTICLE SPECIAL SECTION

\title{
Human Folly and Border Fences: Looking to Non-Human Actors at the Indo-Bangladesh Border
}

\author{
Uddipta Ranjan Boruah *
}

The obsession with inter-state territorial borders and the associated paraphernalia of border management and security makes borders and their management a primarily human-centric discourse. This paper makes an attempt at introducing the agency of rivers as non-human actors-or rather as actants-in shaping and managing international borders. The paper looks specifically at the riverine sector of the Indo-Bangladesh border, where the international boundary has been re-negotiated each year by the transnational rivers, primarily the Brahmaputra (also the Gangadhar), through flooding, erosion, and deposition of sediment. By interrogating the role of rivers in shaping the border and border management strategies, the paper argues that humans, despite persisting as the primary agents in border management, are not the only actors. Drawing on Actor Network Theory (ANT), a case is made to appreciate the general symmetry between humans and non-humans as a-priori equal. Incorporating both in an actor-network may provide insights into border management in complex borderlands.

"The waters flowing under Nihombashi in Edo and the waters in the rivers in China, and Holland are one stream without any barrier" - Japanese Scholar Hayashi Shihei (cited in Smith: 2017, 99)

\section{Introduction}

The study of inter-state borders have mostly been obsessed and confined to the territorial demarcation of the limits of respective sovereign units. Two of the most common concerns associated with inter-state borders have been of border management and security. The continuous attempts at walling and fencing borders have thus, in some way or other remained constants in border discourses. In all of this, the role and agency of the human actor seems to be predominant. The task of defining and delimiting of borders and the designing and implementing of the paraphernalia associated with border management is mostly human centric-either planned and implemented by humans or aimed at checking human movement.

The first section of the paper thus shows the dominance of territorial inter-state borders as the most convincing understanding concerning borders. Coupled with this dominance, the associated paraphernalia of border management through walling or fencing therefore primarily perpetuates a human-centric discourse. The paper then picks up the case of

\footnotetext{
* Uddipta Ranjan Boruah, PhD Candidate, Department of International Relations, South Asian University, New Delhi, India. Twitter: @RanjanUddipta
} 
the India-Bangladesh border fencing project to show how natural phenomena such as flooding and erosion caused by the Brahmaputra fails this human-centred narrative of border walling or management. As an alternative to the human-centric discourse on borders, the next part of the paper analyses the possibility of incorporating the river as a non-human actant in border management. This part draws briefly from Actor Network Theory (ANT) in proposing the possibility of incorporating the non-human into the discourse on border management for a more nuanced understanding of borders.

\section{The Dominance of Inter-State Territorial Borders}

The relevance of territorial borders has been much emphasised in the discourse on international boundaries. This accrues to a great extent to the dominance of the political geographers in the study of borders. The systematic study of borders begun initially as an engagement for the political geographers and focused largely on "descriptive analyses of boundaries, their location and the political and historical processes leading to their demarcation" (Newman 2006a, 145).

Being the fundamental subject matter for the political geographers, borders have traditionally been understood, for examples, "as constituting the physical and highly visible lines of separation between political, social and economic spaces" (Newman 2006a, 144); "Political geographers and political scientists have for a long time perceived boundaries as fixed, stable empirical entities which divide the global space into bounded units that change mainly as a consequence of conflicts" (Paasi 1998, 69); "Very often different from the usual general perception, in the conventional academic phraseology borders are conceptualised as dividing lines between two states" (Tripathi 2015, 1); and "In the traditional sense, borders are considered as a line separating two sovereign territories" (Bhardwaj 2016, 111).

The international system is replete with hard territorial lines and "the current world harbours some 200 states and more than 300 land borders between them, and in addition there are scores of sea boundaries" (Paasi $2011,13)$. With the signing of the Treaty of Westphalia, "the field of politics was formally differentiated into distinct domestic and international spheres, based on internal political hierarchy and external geopolitical anarchy" (Teschke 2009, 3). With the associated model of territorial statehood that came along with the preservation of the Westphalian system, and translating from which, borders came to be seen as sharp dividing lines "between one state unit and its neighbours" has, in a way, become the only model of best territorial practice (Agnew 2007, 398). Others add, "In today's international system, all political units are sovereign territorial states, defined by linear boundaries and with theoretically exclusive claims to authority within those lines" (Branch 2014, 2), and "Since the late 19th century, it has been assumed that regardless of place or context, territories must have linear borders, ideally consisting of precise one-dimensional points on the earth's surface, connected by straight lines" (Goettlich 2018, 2). Therefore, despite considerable expansion in the study of borders in the past decades, territorial borders are still the most prevelent notion of political border (Newman \& Paasi 1998; Newman 2003; Newman 2006a; Newman 2006b; Vallet \& David 2012; Tripathi 2015).

\section{The Predominantly ‘Human' Endeavour of Walling and Excluding}

In addition to the prevailing salience of territorial inter-state borders, a renewed attention towards securitising and restricting them has been yet another considerable phenomenon in the post-9/11 era. In the aftermath of 9/11 terrorist attacks in the United States, the study of borders seem to have attained a "paradigm change" (Newman 2003, 149). Attention was refocused on "the process through which borders can be more rigidly controlled, closing rather than opening, in some cases almost being sealed" (Newman 2003, 149). According to Jones, "The framing of the war on terror as a global and interconnected problem has allowed sovereign states to consolidate power and move substantially closer to the territorial ideal of a closed and bounded container of an orderly population by attempting to lock down political borders" (2009: 1).

One essential tool for border management therefore has been the border wall. On defining a "wall", Vallet and David $(2012,112)$ draw from Sivan (2006) to state that, "depending on the speaker's political stance, ideology and universe of discourse, walled borders are variously referred to as security, separation, apartheid or anti-terror walls, obstacles, partitions, fences, barriers, barricades or borders". The term wall is used by them "to describe border barriers with fixed masonry foundations" (112) and "As of 2010, there were nearly 45 border walls (soon to be 48) totalling more than 29,000 km" (112). Academic works such as those of Andreas and Bierstaker (2003), Goldfarb and Robinson (2003), Hataley and Leuprecht (2018), Nevins (2002), Newman (2003), Payan (2010), Zaiotti (2011), duly highlights the survival and proliferation of border walls.

The phenomenon of walling out neighbours is however not a new strategy for sovereigns. Ranging from the Great Wall of China, Hadrian's Wall and the Antonine Wall in Scotland by the Romans, to its more recent manifestations, one significant element of the very 
bordered international system has been the border wall (Vallet \& David 2012). Building of walls was underway even as the world celebrated the crumbling of the Cold War iron curtain and apartheid in South Africa (Brown 2010, 8). With its decreasing and increasing prominence from time to time across events such as the Cold War, fall of the Berlin Wall, emergence of globalisation, terror attacks of 9/11, the border wall has maintained its existence in the international system. South Asia too is not an exception. India of course is known for its cruder attempts to "wall out Pakistan and Bangladesh" and "wall in disputed Kashmir territory" with objectives such as to "deter refugees from its poorer neighbour, to stake its side in a land dispute and suppress the movement of Islamic guerrillas and weapons" (Brown 2010, 8).

The idea of border walls, their securitisation and control of movement across them mostly revolves around the human agent. That is to say that the walls are for humans (in the understanding of the 'self') and endeavour to primarily keep the human (that is perceived as the 'other') out or to filter the movement of humans. Borders as we know them are either "human creations" Brunet-Jailly (2005), "process of social traditions" Brunet-Jailly (2011), or "artifacts of dominant discursive processes" John Agnew (2008). It appears to be clear that contemporary international borders are primarily endeavours of human agency. The inter-state borders are mostly drawn and redrawn at the political centres away from the borderlands by human hands that are often bereft of realities on the ground. They therefore at times pass through unscalable mountain ranges, meandering rivers, and social lives of borderlands people.

It is interesting to note that bordering is a fight of humans against primarily humans. That is to say that they are attempts by human to keep out or scrutinise and filter primarily humans that are considered as the 'other' (refugees, migrants, aliens, terrorists, etc.) and to secure the 'inside' from the 'outside'. The major function of a border then is "to act as a barrier, protecting the us insiders from the them outsiders" (Newman 2003, 14; see also Oomen 1995; Sibley 1995). The argument is even more convincing in the contemporary era of walled inter-state borders.

To further support this claim, a brief mention of some well known border walling projects can be cited.

- US-Mexico Border: The Executive Order 13767, also known as the Executive Order: Border Security and Immigration Enforcement Improvements, of the US President Donald Trump issued on January 25, 2017, aims to "secure the southern border of the United States through the immediate construction of a physical wall on the southern border" (US Executive Order 13767, 2017: Section 2). The wall is inter alia meant to keep out "aliens who illegally enter the United States" (Section 1). The order further claims that "continued illegal immigration presents a clear and present danger to the interests of the United States" (Section 1). Section 5 of the Order therefore proposes for the construction of detention facilities "to detain aliens at or near the land border with Mexico" (Section 5).

- India Bangladesh Border Fence: The Assam Accord explicitly mentions the rationale of the fence to be to prevent "future infiltration" and "prevent infiltrators crossing or attempting to cross it" (Assam Accord 1985).

- Botswana Zimbabwe Fence:In 2003, the government of Botswana proposed the erecting of a fence along its border with Zimbabwe. Although the Botswana government calls it an attempt to keep out foot and mouth disease among livestock, the Zimbabwean side claims that it is devised to keep out "humans from Zimbabwe” (Brown 2010; Piven 2015).

- Various other human attempts to wall out other humans include Uzbekistan fencing out Kyrgyzstan to prevent "Islamic terrorists", Brunei walling out "immigrants and smugglers coming from Limbang", China walling out the "tide of Korean refugees" etc. (Brown 2010).

It gives us ground to claim therefore that border walls inter alia revolve around the human agent to the extent that on the one hand they are aimed at keeping out "aliens", refugees", "terrorists", and "smugglers", and on the other hand they are devised and erected by the human itself. The walling or fencing project of the human agent, however, this paper argues, has failed on many occasions. One instance is the fencing project along the India-Bangladesh border, specifically the riverine stretch of the border in Assam, India. The perennial flooding and erosion of some of the border areas has been undermining the human centric approach to physically fencing the border, as the border fence is washed away every time including considerable amount of territory. The proposal to fence the border was accepted by the Government of India in 1985 and despite repeated attempts all these years to physically fence the border, the project is still incomplete.

\section{River, Flood, Erosion and the Mockery of Human Endeavour}

Three major challenges that the border fencing project along the particular section of the border in Assam faces are the changing course of rivers (mainly the Brahmaputra, but also the Gangadhar), perennial flooding and washing away of border posts and fence, 


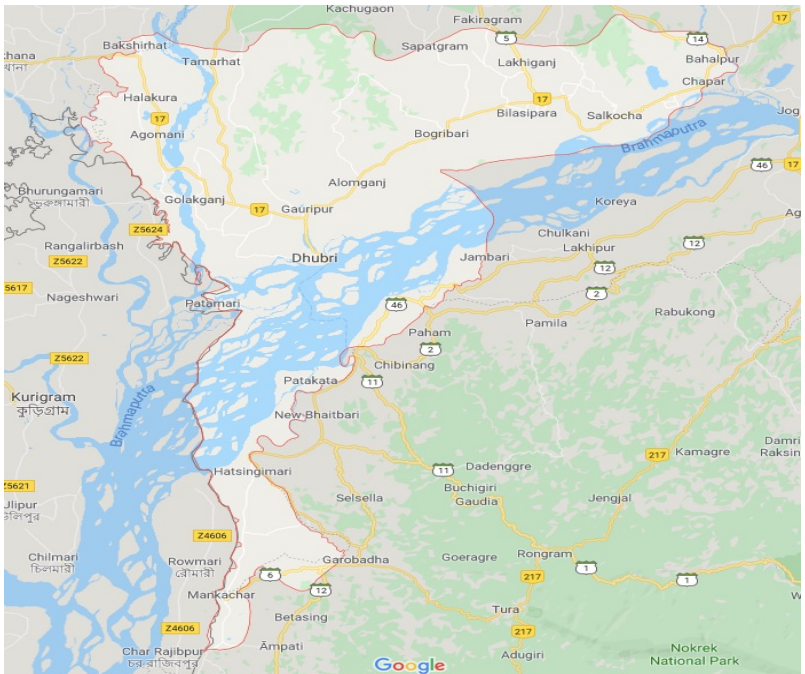

Figure 1. Map. Source: Google Maps.

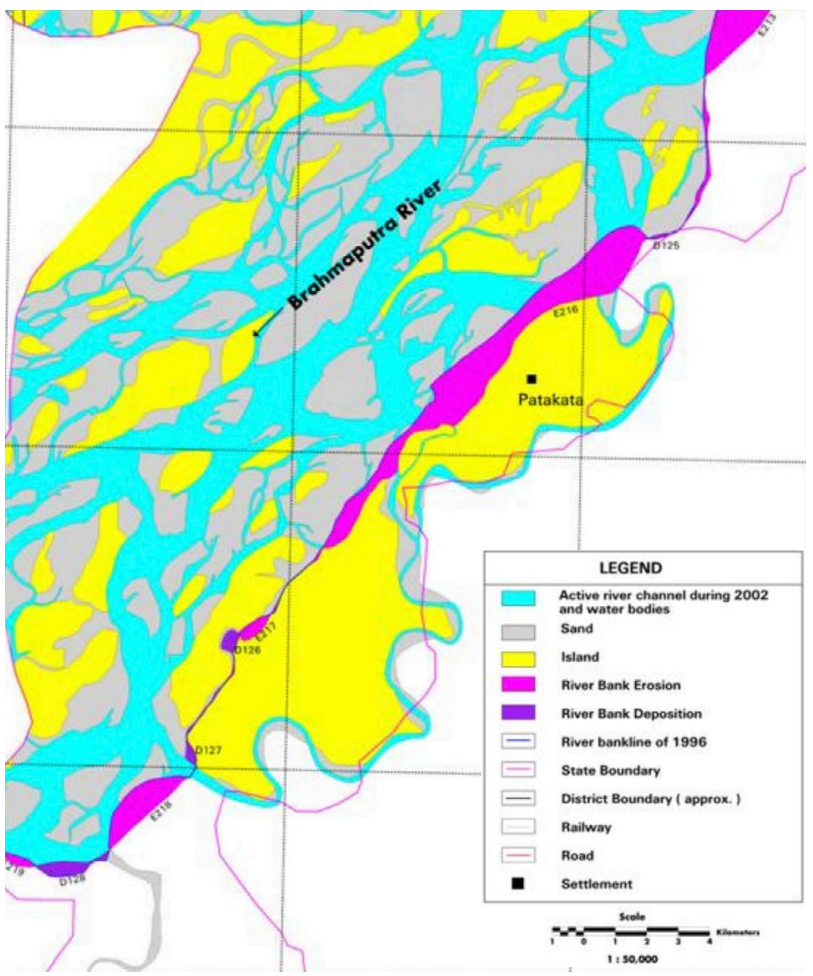

Figure 2. Bank Erorsion of Brahmaputra and Barak Rivers Assam using Satellite Remote Sensing. Source: Central Water Commission, Plate 34 (map placement slightly modified). http://old.cwc.gov.in/main/downloads/ brahmputra.pdf

Figure 3. Publicly available images of river damage to border fence. Source (right top): https://www. telegraphindia.com/states/north-east/border-fenceswashed-away/cid/322247 (right bottom): https://www. indiatoday.in/india/photo/assam-floods-pose-threat-tonational-security-367848-2012-07-03/4 erosion and alteration of borderland territory. This accrues to some of the characteristic features of the major river of the region, Brahmaputra itself. Some of them deserve brief mention here because the crisis that the paper talks about is dependent on them. First, the Brahmaputra is the second-highest sediment-carrying river in the world (Goswami 1985). Flowing through steep slopes of hills upstream and accompanied by high intensity of rainfall and seismicity of the area, the river brings down huge loads of sediment (Mahanta \& Saikia 2015). Due to the sudden fall in the slope as it approaches the lower catchment areas in Assam the river then deposits a great amount of the silt across the flood plains of Assam. This, in a way makes flooding a perennial phenomenon in the region. Second, and related to the first to some extent, the river is "prone to wide-scale channel migration and is a classic example of a braided river" (Mahanta \& Saikia 2015, 155). As a result, it can be seen in the map (Figure 1) that the river multiplies into several smaller streams before it leaves the Indian border. Third, and in addition to the above two, "in no other river is the bank erosion hazard as critical as in the Brahmaputra valley" (Mahanta \& Saikia 2015, 155).

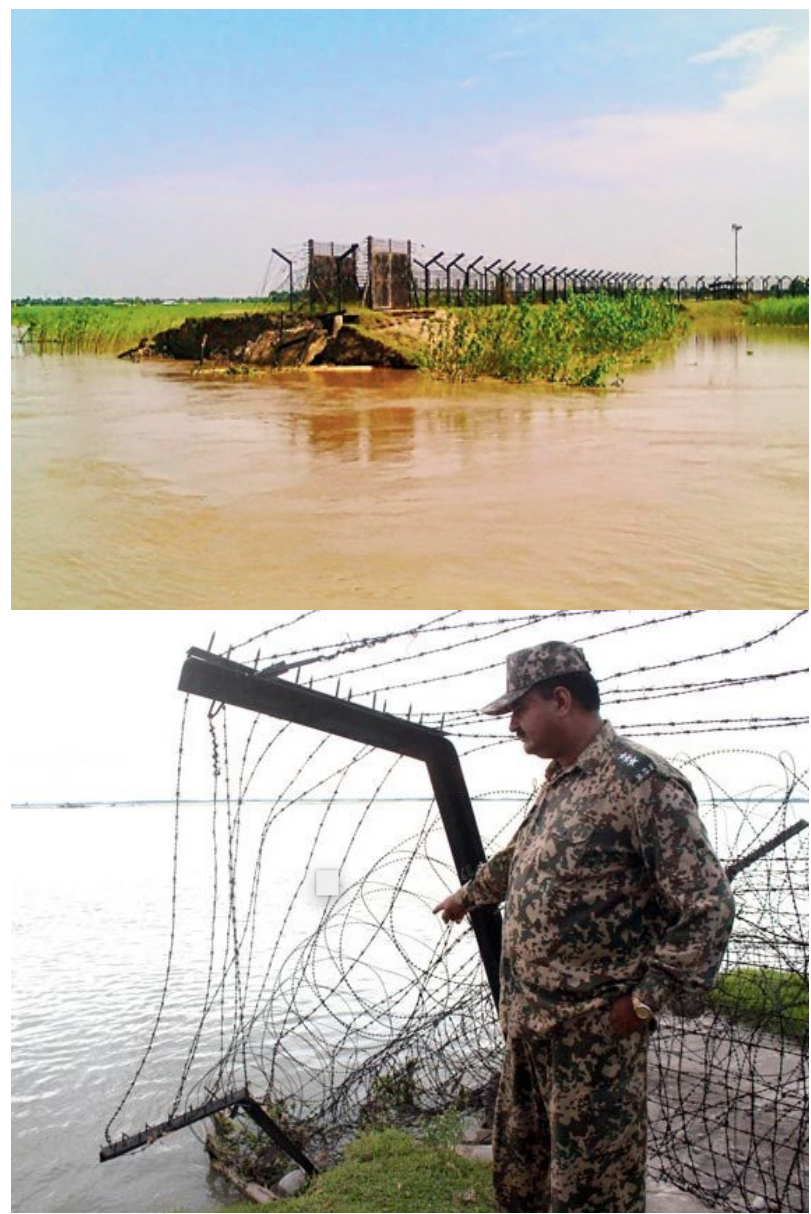


An extract of the erosion data of the Brahmaputra worked out by the Central Water Commission (Figure 2) gives a better classification of the border area into the sand, island, active river channel, and bank erosion.

A brief glance at the map is sufficient enough to highlight the complexity of fencing the international border here. The braided tracts of the river that range sometimes around four to five kilometres, and sometimes smaller, overlap during the monsoon. They deposit sediment as sand and islands in the dry season. Annual flooding by the river inundates segments of the international border including the border fence and BSF border posts (Dutta Choudhury 2013). In addition to inundation for weeks at length, several meters of the border fence are washed away by immense current of the flooding river (Sharma 2014; Karmakar 2019; Mondal 2019).

Images of the border fence (Figure 3) further illustrate the claims.

The same is true in case of the Karimganj sector of the international border in Assam wherein the Kushiyara, a distributary of the Barak river gets into the shoes of the Brahmaputra. The barbed wire fence in Karimganj too are washed away by the perennial flooding and river bank erosion caused by the Kushiyara (Times of India 2011). Also same is the case in Tripura accruing to Muhuri river.

To further concretise the point, a brief list of news items are presented below to give a sense of the scenario of the borderland.

- Time8 News: "The devastating floods caused by incessant rain over the past few days has washed away a vast stretch of a road along with a portion of the barbed wire fencing along the porous Indo-Bangla International Border (IB) at the Asmer-Alga area in South-Salmara Mankachar district of Assam... Around 15 meters of the road along with the fence near 1051-6S border post was washed away by flood waters on July 15th, 2019" (Mondal 2019).

- The Deccan Herald: "About 170 metre of the border fence at Asmer Alga under the Sisumara border outpost in Mankachar, Assam was washed away in July 2019 by the strong currents of the surging Brahmaputra" (Karmakar 2019).

- The Telegraph: "In Golokganj border sector, 222 metres of barbed wire fencing has been totally washed away owing to erosion by the Gangadhar river and still poses a threat to the rest of the fencing along the border" (Sharma 2014).
- The Times of India: "The erosion caused by the Kushiara river is posing a serious threat to the IndoBangladesh border fencing that has been constructed along the bank of the river in Karimganj district... In the border village of Jabainpur, the swelling river has destroyed 300 metre of barbed fencing in the past week. The erosion may also destroy the Jabainpur BOP of the BSF, a source said" (Times of India 2012).

- The Assam Tribune: "The erosion of river banks along the border has led to the collapse of the barbed wire fence, and damaged roads and border lines in many areas... Seasonal floods and heavy rains have made the border fence collapse... The collapse of border fencing and roads has allowed perpetrators to have a free run of unlawful activities" (Assam Tribune 2012).

\section{Agency of the Non-human: River as Actant}

It is now fairly apparent that the taken-for-granted status of the human actor in matters of border management is incomplete in understanding complex borders. Actor Network Theory (ANT) (Callon 1986, 1991; Latour 1987, 1992, 1993) however, enriches understandings of inter-state border management. The major takeaway from the ANT is its focus on alternatives to the "anthropocentrism and sociocentrism" of social sciences (Latour 1997) and the manner in which it looks at the minor distinction between actors and actants.

An actor in ANT is a semiotic definition-an actant-that is, something that acts or to which activity is granted by others. It implies no special motivation of human individual actors nor of humans in general. An actant can literally be anything provided it is granted to be the source of an action (Latour 1997).

Without engaging comprehensively in the specificities of ANT, this paper briefly draws from the following essential ideas of the ANT. The following concepts as compiled by Jackson (2015) which also borrows from Walsham (1997) are important for this paper:

- "An actor/actant ... any material, i.e. human beings or nonhuman actors / actants;

- Actor-network ... Related actors in a heterogeneous network of aligned interests;

- General symmetry ... The symmetrical treatment of humans and nonhumans as a priori equal;

- "The idea that neither a human nor a nonhuman is pure, that is, either human hybridity or nonhuman in an absolute sense but rather entities produced in associations between the former and the latter" (Jackson 2015, 30). 
Additionally, one of the distinguishing contributions of the ANT is:

its attribution of agency to nonhumans, including animals, materials, ideas, and concepts, acknowledging the ability of any entity (or actant) to make itself indispensable to its relationships with others and, by extension, to the continuation of the network" (Dwiartama \& Rosin 2014, 1).

Drawing from ANT, and keeping in mind the prominent role that the rivers have played in the India-Bangladesh borderlands it can therefore be argued that it is necessary to consider general symmetry between the human and the river as a priori equals in negotiating borders. The elevation of the river as an actant within the actor-network of border management makes it possible to engage with the various techniques of border management that have been made essential as a result. Allowing sufficient agency to the river makes the alternative approaches to border management along the India-Bangladesh border more relevant.

\section{River and Border Management: Alternatives}

As it appears, the idea of erecting a physical fence along the entire length of the India-Bangladesh border has not been a very successful project. The negotiating role that the river plays in the borderland has made essential various alternative approaches to border management. "Non-feasibility" along a considerable segment has been explicitly accepted by the Home Ministry. While duly accepting that "at various places, it is not possible to erect Border Fence due to the geographical barriers" the Ministry of Home Affairs eventually implemented some of the non-physical bordering techniques. BOLD-QIT (Border Electronically Dominated QRT Interception Technique) under CIBMS (Comprehensive Integrated Border Management system) on India-Bangladesh border in Dhubri District of Assam was inaugurated on March 5, 2019 by Union Home Minister, Rajnath Singh (PIB, 2019). There has also been huge expenditures on alternatives such as hovercraft and floating platforms for riverine borders.

The fact that despite the immense might of a state like India the physical fence cannot in any ways be sustained in certain segments of the border provides us with an entry point to consider the role of elements beyond the human agent in negotiating international borders. There may be a need for considering the rivers as not merely passive but an agent in a network of agents negotiating the India-Bangladesh border. This requires a shift from "self-assertive behaviour" of the human towards a more "integrative" approach (Capra 1996, 10). There is a need to realize that the human although being a primary actor in negotiating inter-state borders, is not the only actor. It calls for the realisation that elements beyond the human are not just part of our "global life support system but also that humanity need not be the mind of the planet" (Smith 2017, 109). The human should see itself as "pirmus inter pares" (first among equals) rather than as guiding intelligence" (Smith 2017, 109). If after witnessing such impact made by the rivers on the international border resulting in greater political ramifications, we still fail to accommodate the influence of agents beyond the human, political solutions are doomed to fail due to an "ignorance of variables" (Bryant 2011).

\section{Works Cited}

All hyperlinks last accessed December 2021 unless specified.

Agnew, J. 2007. "No Borders No Nations: Making Greece in Macedonia" Annals of the Association of American Geographers 97(2 June): 398-422. https://doi. org/10.1111/j.1467-8306.2007.00545.x

Agnew, J. 2008. "Borders on the Mind: Re-framing Border Thinking" Ethics \& Global Politics 1(4): 175-91. https://doi. org/10.3402/egp.v1i4.1892

Andreas, P. and Bierstaker, T. (eds.) 2003. The Re-bordering of North America: Integration and Exclusion in a New Security Context. New York: Routledge.

Assam Tribune. 2012. "River erosion upsets BSF at Indo-Bangla border" Assam Tribune (May 8). http://www. assamtribune.com/scripts/detailsnew.asp?id=may0812/ at0151 [Accessed on 10/11/2019].

Bhardwaj, Sanjay K. 2016. "India-Bangladesh Border Governance: Issues and Challenges" International Studies 50(1\&2): 109-129. https://doi.org/10.1177/0020881716654387

Branch, Jordan. 2014. The Cartographic State: Maps, Territory and the Origins of Sovereignty. Cambridge: Cambridge University Press.

Brown, Wendy. 2010. Walled States, Waning Sovereignty. Brooklyn, New York: Zone Books.

Browning, C.S.andP.Joenniemi.2004."Contending discourses of marginality: The case of Kaliningrad" Geopolitics 9(3): 699-730. https://doi.org/10.1080/14650040490478747

Brunet-Jailly, E. 2005. "Theorising Borders: An Interdisciplinary Perspective" Geopolitics 10(4): 633-649. https://doi.org/10.1080/14650040500318449

Brunet-Jailly, Emmanuel. 2011. "Special Section: Borders, Borderlands and Theory: An Introduction" Geopolitics 16(1): 1-6. https://doi.org/10.1080/14650045.2010.493765

Bryant, L.R. 2011. The Democracy of Object. Ann Arbor, Michigan: Open Humanities Press, University of Michigan Library.

Callon, Michael. 1986. "Some Elements of a Sociology of Translation: Domestication of the Scallops and the Fishermen of St Brieuc Bay" The Sociological Review 32(1). https://doi.org/10.1111/j.1467-954X.1984.tb00113.x

Callon, Michael. 1991. "Techno-Economic Networks and Irreversibility" in A Sociology of Monsters: Essays on Power, Technology and Domination, edited by J. Law, 132-161. London: Routledge. 
Capra, Fritjof. 1996. The Web of Life: A New Scientific Understanding of Living System. Michigan: Anchor Books.

Dutta Choudhury, R. 2013. Porous Border. Guwahati: Bhabani Books.

Dwiartama, A., and C. Rosin. 2014. "Exploring Agency Beyond Humans: The Compatibility of Actor-Network Theory (ANT) and Resilience Thinking" Ecology and Society 19(3): 28. http://dx.doi.org/10.5751/ES-06805-190328

Goettlich, Kerry. 2018. "The Rise of Linear Borders in World Politics', European Journal of International Relations 1(26): 1-26. https://doi.org/10.1177/1354066118760991

Goldfarb, D., and W. Robinson. 2003. "Risky Business: U.S. Border Security and the Threat to Canadian Exports" C.D. Howe Institute Commentary 177. https://www.cohowe.org/ public-policy-research/risky-business-us-border-securityand-threat-canadian-exports

Goswami, D.C. 1985. "Brahmaputra River, Assam, India: Physiography, Basin Denudation, and Channel Aggradation" Water Resources Research 21(7): 959-978. https://doi.org/10.1029/WR021i007p00959

Hataley, T. and C. Leuprecht. 2018. "Determinants of Cross-Border Cooperation" Journal of Borderlands Studies 33(3): 317-328. https://doi.org/10.1080/08865655 .2018 .1482776

Jackson, S. 2015. "Toward an Analytical and Methodological Understanding of Actor-network Theory" Journal of Arts and Humanities 4(2): 29-44. https://doi.org/10.18533/ journal.v4i2.210

Jones, R. 2009. "Geopolitical Boundary Narratives, the Global War on Terror, and Border Fencing in India" Transactions of the Institute of British Geographers 34(3): 290-304. https://doi.org/10.1111/j.1475-5661.2009.00350.x

Karmakar, S. 2019. "Floods break Indo-Bangla border fence in Assam" Deccan Herald, Guwahati. https://www. deccanherald.com/national/east-and-northeast/floodsbreach-indo-bangla-border-fence-in-assam-749138.html

Latour, B. 1987. Science in Action: How to Follow Scientists and Engineers Through Society. Open University Press: Milton Keynes.

Latour, B. 1992. "Where are the Missing Masses? The Sociology of a Few Mundane Artefacts" in Shaping Technology / Building Society: Studies in Sociotechnical Change, edited by W.E. Bijker, and J. Law, 205-224. Cambridge, Mass: MIT Press.

Latour, B. 1993. We Have Never Been Modern. London: Harvester Wheatsheaf.

Latour, B. 1997. "On Actor-Network Theory: A few Clarifications." Net Time. http://www.nettime.org/ListsArchives/nettime-l-9801/msg00019.html

Mahanta, C. and L. Saikia. 2015. "The Brahmaputra and Other Rivers of the North-East" in Living Rivers, Dying Rivers, edited by R.R. Iyer, 149-181. New Delhi: Oxford University Press.

Mondal, K. 2019. "Wire fencing along Indo-Bangla border washed away in South-Salmara Mankachar" Time8 News, Assam. https://www.time8.in/breaking-wire-fencing-alongindo-bangla-border-washed-away-in-south-salmaramankachar/

Nail, T. 2016. Theory of the Border. Oxford: Oxford University Press.
Nevins, J. 2002. Operation Gatekeeper: The Rise of the Illegal Alien and the Making of the U.S.- Mexico Border. New York: Routledge.

Newman, D. 2003, "On Borders and Power: A Theoretical Framework" Journal of Borderlands Studies 18(1): 13-25. https://doi.org/10.1080/08865655.2003.9695598

Newman, D. (2006a) "The Lines that Continue to Separate Us: Borders in our 'Borderless' World" Progress in Human Geography 32(2): 143-161. https://doi. org/10.1191/0309132506ph599xx

Newman, D. 2006b. "Borders and Bordering:Towards an Interdisciplinary Dialogue" European Journal of Social Theory 9(2): 171-186. https://doi. org/10.1177/1368431006063331

Newman, D. and A. Paasi. 1998. "Fences and Neighbours in the Postmodern World: Boundary Narratives in Political Geography" Progress in Human Geography 22(2):186-207. https://doi.org/10.1191\%2F030913298666039113

Oommen, T.K. 1995. "Contested Boundaries and Emerging Pluralism" International Sociology 10(3 September): 251-268. https://www.jstor.org/stable/23619647

Paasi, A. 1998. "Boundaries as Social Processes: Territoriality in the World of Flows" Geopolitics 3(1): 69-88. https://doi. org/10.1080/14650049808407608

Paasi, A. 2005. "Generations and the 'Development' of Border Studies" Geopolitics 10: 663-71. https://doi. org/10.1080/14650040500318563

Paasi, A. 2011. "A Border Theory: Un unattainable Dream or a Realistic Aim for Border Scholars?" in The Ashgate Research Companion to Border Studies, edited by D. WastIWalter, 11-31. London: Routledge.

Payan, T. 2010. The Three US-Mexico Border War: Drugs, Immigration and Homeland Security. Westport: Praeger Security International.

Piven, B. 2015. "Walls of the World Aim to Keep Unwanted Foreigners Out, Hold Prosperity In" Al-Jazeera America. http://america.aljazeera.com/articles/2015/9/5/wallsworld-keep-foreigners-out.html

Press Information Bureau. 2019. "Shri Rajnath Singh to inaugurate BOLD-QIT project along international border in Dhubri, Assam tomorrow" Press Information Bureau. https://pib.gov.in/Pressreleaseshare.aspx?PRID=1567263

Sharma, B. Kr. 2014. "Border Fences Washed Away" The Telegraph, Guwahati. https://www.telegraphindia. com/states/north-east/border-fences-washed-away/ $\mathrm{cid} / 322247$

Sibley, D. 1995. Geographies of Exclusion, Society and Difference in the West. London: Routledge.

Smith, J.L. 2017. "I, River? New Materialism, Riparian non-human Agency and the Scale of Democratic Reform" Asia Pacific Viewpoint 58(1): 99-111. https://doi.org/10.1111/ apv. 12140

Teschke, B. 2003. The Myth of 1648: Class Geopolitics and the Making of Modern International Relations. London and New York: Verso.

Times of India. 2012. "Kushiara destroys 300 metre border fence in Karimganj" (May 27). http://timesofindia. indiatimes.com/articleshow/13541070.cms?utm_ source=contentofinterest\&utm_medium =text\&utm_ campaign=cppst 
Tripathi, D. 2015. "Interrogating Linkages Between Borders, Regions, and Border Studies" Journal of Borderlands Studies 10: 1-13. https://doi.org/10.1080/08865655.2015.1042010

United States Executive Order 13767. 2017. "Executive Order: Border Security and Immigration Enforcement Improvements" https://www.whitehouse.gov/presidentialactions/executive-order-border-security-immigrationenforcement-improvements/ [Accessed on 07/11/2019].

Vallet, E. and C.-P. David. 2012. "The $(\mathrm{Re})$ Building of the Wall in International Relations" Journal of Borderlands Studies 27(2): 111-119. https://doi.org/10.1080/08865655.2012.687211

Walsham, G. 1997. "Actor-network Theory and IS Research: Current Status and Future Prospects" in Information Systems and Qualitative Research, edited by A. Lee, J. Liebenau, and J. DeGross. Chapman and Hall: London.

Zaiotti, R. 2011. Cultures of Border Control: Schengen and the Evolution of European Frontier. Chicago: University of Chicago Press. 